\title{
Telaah Implementasi Kurikulum 2013: Tinjauan Pada Rencana Pelaksanaan Pembelajaran (RPP) Mata Pelajaran Ilmu Pengetahuan Alam
}

\author{
Arghob Khofya Haqiqi \\ Program Studi Tadris IP A, Institut Agama Islam Negeri Kudus, Indonesia \\ e-mail: \\ arghobhaqiqi@stainkudus.ac.id
}

\begin{abstract}
.
Research has been conducted on the application of the 2013 curriculum through analysis of learning implementation planning (RPP) prepared by science teachers at SMP Kartika III-2 Semarang. The method used in this study uses descriptive qualitative research. Data collection techniques are carried out using observation sheets, documentation, and interviews. The results of the analysis carried out in the lesson plan reviewed, conclusions were obtained about the application of the 2013 curriculum that had been well made in the aspects of learning planning contained in the lesson plan. All components have been included in the lesson plan. The teacher is also enthusiastic and tries to use saintifice method in learning. However, there are several obstacles that must be corrected in the selection section of teaching material.
\end{abstract}

Keywords: analysis, 2013 curriculum, RPP

\begin{abstract}
ABSTRAK.
Telah dilakukan penelitian terhadap penerapan kurikulum 2013 melalui analisis rencana pelaksanaan pembelajaran (RPP) yang disusun oleh guru IPA di SMP Kartika III-2 Semarang. Metode yang digunakan dalam penelitian ini menggunakan penelitian kualitatif deskriptif. Teknik pengumpulan data yang dilakukan dengan menggunakan lembar observasi, dokumentasi, dan wawancara. Hasil analisis yang telah dilakukan pada RPP yang ditelaah, diperoleh kesimpulan bahwa penerapan kurikulum 2013 sudah berjalan dengan baik dalam aspek perencanaan pembelajaran yang tertuang dalam RPP. Semua komponen telah tercantum dalam RPP. Guru juga antusias dan berusaha menggunakan pendekatan saintifik dalam pembelajaran. Namun, terdapat beberapa hambatan yang harus diperbaiki terutama pada bagian pemilihan materi ajar.
\end{abstract}

Kata kunci: analisis, kurikulum 2013, RPP

\section{PENDAHULUAN}

Pengembangan Kurikulum 2013 merupakan langkah lanjutan Pengembangan Kurikulum Berbasis Kompetensi yang telah dirintis pada tahun 2004 dan KTSP 2006 yang mencakup kompetensi sikap, pengetahuan, dan keterampilan secara terpadu.Kurikulum 2013 yang telah diterapkan pemerintah memberikan implikasi yang tidak sedikit terhadap pembelajaran yang akan dilakukan oleh guru di kelas, khususnya guru IPA. 
Hal ini dikarenakan dalam kurikulum 2013, mata pelajaran IPA tidak lagi dibedakan menjadi mata pelajaran Fisika, Biologi, dan Kimia. Mata pelajaran IPA disajikan dalam bentuk integrasi dari fisika, biologi, dan kimia.

Selain itu, pembelajaran yang dilakukan oleh guru dalam kurikulum 2013 harus memiliki kriteria pendekatan saintifik sebagai ciri utama dari kurikulum 2013. Hal-hal tersebut menjadi tantangan bagi guru-guru mata pelajaran IPA. Karena sebelumnya mata pelajaran IPA yang disajikan di SMP tidak terintegrasi atau terpisah-pisah. perubahan pembelajaran di kelas juga menuntut guru untuk lebih kreatif dan terus berubah agar pembelajaran IPA tidak lagi dilakukan hanya dengan ceramah di kelas yang pada umumnya guru-guru lakukan (Winny, 2014)

Kurikulum 2013 merupakan kurikulum yang dikeluarkan oleh pemerintah dimana kurikulum tersebut menitikberatkan penggunaan pendekatan saintifik, penilaian autentik serta tematik integratif dalam pembelajarannya. Pada impelementasi kurikulum ini diharapkan mampu mencetak generasi Indonesia yang kritis dan kreatif sesuai dengan tuntutan perkembangan zaman sekarang ini. Gerde, H. K (2013) menjelaskan bahwa pendidikan dengan menggunakan pendekatan saintifik berpotensi untuk meletakkan landasan penting untuk pengetahuan serta minat anak-anak dalam ilmu pengetahuan.

Berlandaskan Undang-Undang Republik Indonesia nomor 20 tahun 2003 tentang Sistem Pendidikan Nasional dan Peraturan Pemerintah (PP) nomor 19 tahun 2005 tentang Standar Nasional Pendidikan (SNP), Pemerintah melalui Departemen Pendidikan Nasional, berkewajiban menetapkan berbagai peraturan tentang standar penyelenggaraan pendidikan di seluruh wilayah Negara Kesatuan Republik Indonesia (NKRI). Standar nasional pendidikan yang dimaksud meliputi: standar isi, standar kompetensi lulusan, standar proses, standar pendidik dan tenaga kependidikan, standar sarana dan prasarana, standar pengelolaan, standar pembiayaan, dan standar penilaian pendidikan.

Peraturan Pemerintah nomor 19 tahun 2005 yang berkaitan dengan standar proses mengisyaratkan bahwa guru diharapkan dapat mengembangkan perencanaan pembelajaran, yang kemudian dipertegas melalui Peraturan Menteri Pendidikan Nasional (Permendiknas) nomor 41 tahun 2007 tentang Standar Proses, yang antara lain mengatur tentang perencanaan proses pembelajaran yang mensyaratkan bagi pendidik pada satuan pendidikan untuk mengembangkan rencana pelaksanaan pembelajaran (RPP), khususnya pada jenjang pendidikan dasar dan menengah jalur formal, baik yang menerapkan sistem paket maupun sistem kredit semester (SKS).

Penelitian evaluasi implementasi Kurikulum 2013 telah dilakukan di beberapa sekolah. Krissandi, (2015) menemukan ada kendala guru sekolah dasar dalam mengimplementasikan Kurikulum 2013 yang berasal dari pemerintah, institusi, guru, orang tua peserta didik dan guru. Agustyana, Widodo, (2014) menjelaskan kesiapan implementasi Kurikulum 2013 di Sekolah Dasar Negeri Banaran Kertosono pada aspek kepemimpinan sekolah telah sangat baik, kreativitas guru baik, aktivitas peserta didik baik dan lingkungan akademik sangat baik. Demikian pula hasil evaluasi pendampingan yang dilakukan oleh Pusat Penelitian dan Pengembangan (Puslitbang) Kementerian Pendidikan dan Kebudayaan (Kemendikbud) pada sekolah piloting menunjukkan bahwa pemahaman guru terhadap buku, RPP, proses pembelajaran, dan penilaian sangat baik.

Salah satu komponen yang terpenting dalam implementasi kurikulum 2013 adalah penyusunan Rencana Pelaksanaan Pembelajaran (RPP) yang disusun oleh guru yang mengampu mata pelajaran. RPP merupakan rencana yang menggambarkan prosedur dan pengorganisasian pembelajaran untuk mencapai satu kompetensi dasar. (Depdiknas, 2007). RPP paling luas mencakup 1 (satu) kompetensi dasar yang meliputi 1 (satu) atau beberapa indikator untuk 1 (satu) kali pertemuan atau lebih. 
Sebuah RPP yang baik harus memenuhi komponen sebagai berikut: (1) Identitas Mata Pelajaran: mengandung identitas yang jelas; (2) Standar Kompetensi: sesuai dengan kurikulum; (3) Kompetensi Dasar: sesuai dengan kurikulum; (4) Indikator Pencapaian Kompetensi: mengandung kata-kata yang operasional dan dapat diukur; (5) Tujuan Pembelajaran: mencakup tiga ranah belajar, kognitif, sikap, dan psikomotor; (6) Materi Ajar: Materi yang diberikan kepada peserta didik harus sesuai dengan tingkat perkembangannya; Pengorganisasian materi harus menarik agar dapat mendorong siswa untuk belajar; (7) Alokasi Waktu: kesesuaian pengaturan waktu berdasarkan keperluan setiap langkah; (8) Metode Pembelajaran: ketepatan pemilihan metode; (9) Kegiatan Pembelajaran: memperlihatkan proses belajar yang mengaktifkan siswa dalam mencapai ketiga ranah belajar; (10) Penilaian Hasil Belajar: mengacu pada tujuan pembelajaran; dan (11) Sumber Belajar: menguakan berbagi macam sumber belajar. (Wikanengsih, 2015)

Pada lampiran Permendiknas nomor 16 tahun 2007 tentang Standar Kualifikasi Akademik dan Kompetensi Guru, juga diatur tentang berbagai kompetensi yang harus dimiliki oleh pendidik, baik yang bersifat kompetensi inti maupun kompetensi mata pelajaran. Bagi guru pada satuan pendidikan jenjang Sekolah Menengah Atas (SMA), baik dalam tuntutan kompetensi pedagogik maupun kompetensi profesional, berkaitan erat dengan kemampuan guru dalam mengembangkan perencanaan pembelajaran secara memadai.

Dalam rangka mengimplementasikan program pembelajaran yang sudah dituangkan dalam silabus, guru harus menyusun rencana pelaksanaan pembelajaran (RPP) yang merupakan pegangan bagi guru dalam melaksanakan pembelajaran baik di kelas, labolatorium dan lapangan untuk setiap kompetensi dasar (Turpin, 2004). Oleh karena itu, apa yang tertuang di dalam RPP memuat hal-hal yang langsung berkaitan dengan aktifitas pembelajaran dalam upaya pencapaian penguasaan kompetensi dasar. Dalam penyusunan RPP guru dituntut untuk mengembangkan pembelajaran sesuai dengan tuntutan kurikulum 2013 yaitu melalui pendekatan saintifik.

Berdasarkan uraian yang telah disebutkan diatas, maka peneliti disini melakukan penelitian terhadap penerapan kurikulum 2013 melalui analisis rencana pelaksanaan pembelajaran (RPP) yang disusun oleh guru IPA di Sekolah Menengah Pertama (SMP).

\section{METODOLOGI}

Metode penelitian yang digunakan dalam penelitian ini menggunakan metode penelitian kualitatif deskriptif untuk mengetahui penerapan kurikulum 2013 pada aspek RPP. Dalam penelitian ini digunakan berbagai macam teknik pengumpulan data, diantaranya menggunakan lembar observasi, dokumentasi, dan wawancara.

Penelitian ini dilakukan di salah satu SMP di Kota Semarang yang dalam proses pembelajarannya telah menggunakan kurikulum 2013 yaitu SMP Kartika III-2 Semarang.

\section{TEMUAN DAN PEMBAHASAN}

Pada analisis Rencana Pelakasanaan Pembelajaran (RPP) ini telah dilakukan analisis berdasarkan komponen-komponen RPP. Komponen RPP ada 9, yaitu identitas mata pelajaran, perumusan indikator, perumusan tujuan pembelajaran, pemilihan materi ajar, pemilihan sumber belajar, pemilihan media belajar, model pembelajaran, skenario pembelajaran, dan penilaian. Hasil analisis terhadap masing-masing data komponen yang terdapat pada RPP dapat dilihat pada tabel 1 dan tabel 2 berikut: 
Tabel 1. Data Analisis RPP Sub Topik Kunci Dikotom

\begin{tabular}{|c|c|c|c|c|}
\hline \multirow[t]{2}{*}{ No } & \multirow{2}{*}{$\begin{array}{cr} & \text { Komponen } \\
\text { A. Identitas mata pelajaran }\end{array}$} & \multicolumn{3}{|c|}{ Hasil Analisis } \\
\hline & & $\begin{array}{l}\text { Tidak } \\
\text { ada }\end{array}$ & $\begin{array}{l}\text { Kurang } \\
\text { lengkap }\end{array}$ & $\begin{array}{l}\text { Sudah } \\
\text { Lengkap }\end{array}$ \\
\hline \multirow[t]{2}{*}{1.} & $\begin{array}{l}\text { Satuan pendidikan,kelas, } \\
\text { program/program keahlian, mata pelajaran } \\
\text { atau tema pelajaran, jumlah pertemuan. }\end{array}$ & & & $\sqrt{ }$ \\
\hline & B. Perumusan indikator & $\begin{array}{l}\text { Tidak } \\
\text { sesuai }\end{array}$ & $\begin{array}{c}\text { Sesuai } \\
\text { sebagian }\end{array}$ & $\begin{array}{c}\text { Sesuai } \\
\text { seluruhnya }\end{array}$ \\
\hline 1. & Kesesuaian dengan KI dan KD. & & & $\sqrt{ }$ \\
\hline 2. & $\begin{array}{l}\text { Kesesuaian penggunaan kata kerja operasional } \\
\text { dengan kompetensi yang diukur. }\end{array}$ & & $\sqrt{ }$ & \\
\hline \multirow[t]{2}{*}{3.} & $\begin{array}{l}\text { Kesesuaian dengan aspek sikap, pengetahuan, } \\
\text { dan keterampilan. }\end{array}$ & & & $\sqrt{ }$ \\
\hline & C. Perumusan tujuan pembelajaran & $\begin{array}{l}\text { Tidak } \\
\text { sesuai }\end{array}$ & $\begin{array}{c}\text { Sesuai } \\
\text { sebagian }\end{array}$ & $\begin{array}{c}\text { Sesuai } \\
\text { seluruhnya }\end{array}$ \\
\hline 1. & $\begin{array}{l}\text { Kesesuaian dengan proses dan hasil belajar } \\
\text { yang diharapkan dicapai. }\end{array}$ & & & $\sqrt{ }$ \\
\hline \multirow[t]{2}{*}{2.} & Kesesuaian dengan kompetensi dasar. & & $\sqrt{ }$ & \\
\hline & D. Pemilihan materi ajar & $\begin{array}{l}\text { Tidak } \\
\text { sesuai }\end{array}$ & $\begin{array}{c}\text { Sesuai } \\
\text { sebagian }\end{array}$ & $\begin{array}{c}\text { Sesuai } \\
\text { seluruhnya }\end{array}$ \\
\hline 1. & Kesesuaian dengan tujuan pembelajaran & & $\sqrt{ }$ & \\
\hline 2. & Kesesuaian dengan karakteristik peserta didik. & & $\sqrt{ }$ & \\
\hline \multirow[t]{2}{*}{3.} & Kesesuaian dengan alokasi waktu. & $\sqrt{ }$ & & \\
\hline & E. Pemilihan sumber belajar & $\begin{array}{l}\text { Tidak } \\
\text { sesuai }\end{array}$ & $\begin{array}{c}\text { Sesuai } \\
\text { sebagian }\end{array}$ & $\begin{array}{c}\text { Sesuai } \\
\text { seluruhnya }\end{array}$ \\
\hline 1. & Kesesuaian dengan KI dan KD. & & & $\sqrt{ }$ \\
\hline 2. & $\begin{array}{l}\text { Kesesuaian dengan materi pembelajaran dan } \\
\text { pendekatan saintifik. }\end{array}$ & & $\sqrt{ }$ & \\
\hline \multirow[t]{2}{*}{3.} & Kesesuaian dengan karakteristik peserta didik & & $\sqrt{ }$ & \\
\hline & F. Pemilihan media belajar & $\begin{array}{l}\text { Tidak } \\
\text { sesuai }\end{array}$ & $\begin{array}{c}\text { Sesuai } \\
\text { sebagian }\end{array}$ & $\begin{array}{c}\text { Sesuai } \\
\text { seluruhnya }\end{array}$ \\
\hline 1. & Kesesuaian dengan tujuan pembelajaran. & & $\sqrt{ }$ & \\
\hline 2. & $\begin{array}{l}\text { Kesesuaian dengan materi pembelajaran dan } \\
\text { pendekatan saintifik. }\end{array}$ & & $\sqrt{ }$ & \\
\hline \multirow[t]{2}{*}{3.} & Kesesuaian dengan karakteristik peserta didik. & & $\sqrt{ }$ & \\
\hline & G. Model Pembelajaran & $\begin{array}{l}\text { Tidak } \\
\text { sesuai }\end{array}$ & $\begin{array}{c}\text { Sesuai } \\
\text { sebagian }\end{array}$ & $\begin{array}{c}\text { Sesuai } \\
\text { seluruhnya }\end{array}$ \\
\hline 1. & Kesesuaian dengan tujuan pembelajaran. & & $\sqrt{ }$ & \\
\hline \multirow[t]{2}{*}{2.} & Kesesuaian dengan pendekatan saintifik. & & $\sqrt{ }$ & \\
\hline & H. Skenario pembelajaran & $\begin{array}{l}\text { Tidak } \\
\text { sesuai }\end{array}$ & $\begin{array}{c}\text { Sesuai } \\
\text { sebagian }\end{array}$ & $\begin{array}{c}\text { Sesuai } \\
\text { seluruhnya }\end{array}$ \\
\hline 1. & $\begin{array}{l}\text { Menampilkan kegiatan pendahuluan, inti, dan } \\
\text { penutup dengan jelas. }\end{array}$ & & $\sqrt{ }$ & \\
\hline 2. & $\begin{array}{l}\text { Kesesuaian kegiatan dengan pendekatan } \\
\text { saintifik. }\end{array}$ & & $\sqrt{ }$ & \\
\hline 3. & $\begin{array}{l}\text { Kesesuaian penyajian dengan sistematika } \\
\text { materi. }\end{array}$ & & $\sqrt{ }$ & \\
\hline \multirow[t]{2}{*}{4.} & $\begin{array}{l}\text { Kesesuaian alokasi waktu dengan cakupan } \\
\text { materi. }\end{array}$ & $\sqrt{ }$ & & \\
\hline & I. Penilaian & $\begin{array}{l}\text { Tidak } \\
\text { sesuai }\end{array}$ & $\begin{array}{c}\text { Sesuai } \\
\text { sebagian }\end{array}$ & $\begin{array}{c}\text { Sesuai } \\
\text { seluruhnya }\end{array}$ \\
\hline 1. & $\begin{array}{l}\text { Kesesuaian dengan teknik dan bentuk } \\
\text { penilaian autentik. }\end{array}$ & & & $\sqrt{ }$ \\
\hline 2. & $\begin{array}{l}\text { Kesesuaian dengan dengan indikator } \\
\text { pencapaian } \mathrm{KD} \text {. }\end{array}$ & & & $\sqrt{ }$ \\
\hline 3. & Kesesuaian kunci jawaban dengan soal. & & & $\sqrt{ }$ \\
\hline 4. & Kesesuaian pedoman penskoran dengan soal. & & & $\sqrt{ }$ \\
\hline
\end{tabular}


Pada komponen identitas mata pelajaran menjelaskan bahwa hasil analisis menunjukkan keterangan sudah lengkap. Hal ini terlihat dari komponen identitas mata pelajaran yang terdiri dari satuan pendidikan, kelas, semester, program/program keahlian, mata pelajaran atau tema pelajaran, dan jumlah pertemuan sudah tercantum dalam RPP.

Pada komponen perumusan indikator terdiri dari kesesuaian dengan KI dan KD, kesesuaian penggunaan kata kerja operasional dengan kompetensi yang diukur, dan kesesuaian dengan aspek sikap, pengetahuan, dan keterampilan. Untuk aspek kesesuaian dengan KI dan KD, hasil analisis menunjukkan sesuai seluruhnya. Untuk aspek kesesuaian penggunaan kata kerja operasional dengan kompetensi yang diukur, hasil analisis menunjukkan sesuai sebagian. Hal ini terlihat dari penggunaan kata kerja memiliki pada indikator 1 dan indikator 2, yang dirasa masih kurang tepat. Sedangkan untuk aspek kesesuaian dengan aspek sikap, pengetahuan, dan keterampilan, hasil analisis menunjukkan sesusai seluruhnya.

Komponen perumusan tujuan pembelajaran terdiri dari kesesuaian dengan proses dan hasil belajar yang diharapkan dicapai dan kesesuaian dengan $\mathrm{KD}$. Untuk aspek kesesuaian dengan proses dan hasil belajar yang diharapkan dicapai, hasil analisis menunjukkan sesuai seluruhnya. Pada proses, guru mengajarkan mengenai kunci dikotom untuk membantu siswa dalam mengklasifikasikan makhluk hidup. Hasil yang diharapkan dicapai sudah sesuai yakni dapat mengklasifikasikan makhluk hidup dengan cara dikotom dan dapat membuat kunci determinasi. Sedangkan untuk aspek kesesuaian dengan $\mathrm{KD}$, hasil analisis menunjukkan sesuai sebagian. Hal ini dapat dilihat pada tujuan pembelajaran tidak mencakup tujuan untuk aspek keterampilan.

Pada komponen pemilihan materi ajar terdiri dari kesesuaian dengan tujuan pembelajaran, kesesuaian dengan karakteristik siswa, kesesuaian dengan alokasi waktu (Fogarty, 1991). Untuk aspek kesesuaian dengan tujuan pembelajaran, hasil analisis menunjukkan sesuai sebagian. Hal ini dapat dilihat pada pemilihan materi ajar tidak ada penjelasan mengenai kunci dikotom. Padahal, substansi dari pertemuan ini ada pada kunci dikotom untuk membekali siswa sebelem mengklasifikasikan makhluk hidup. Untuk aspek kesesuaian dengan karakteristik siswa, hasil analisis menunjukkan sesuai sebagian. Hal ini dapat dilihat pada RPP seharusnya ada penjelasan mengenai cara penggunaan kunci dikotom sehingga siswa kelas VII tidak mengalami kebingungan ketika telah mencapai klasifikasi tumbuhan dan hewan secara dikotom. Untuk aspek alokasi waktu, hasil analisis menunjukkan tidak sesuai. Hal ini dapat diamati ketika proses pembelajaran berlangsung. Pada RPP tercantum alokasi waktu untuk 3 JP, tetapi pelaksanaannya hanya 2 JP.

Komponen pemilihan sumber belajar terdiri dari aspek kesesuaian dengan KI dan KD, kesesuaian dengan materi pembelajaran dan pendekatan saintifik, dan kesesuaian dengan karakteristik peserta didik. Untuk aspek kesesuaian dengan KI dan KD, hasil analisis menunjukkan sesuai seluruhnya. Hal ini dikarenakan sumber belajar yang digunakan merupakan buku baru khusus untuk kurikulum 2013 lagsung dari pemerintah. Untuk aspek kesesuaian dengan materi pembelajaran dan pendekatan saintifik, hasil analisis menunjukkan sesuai sebagian. Hal ini dikarenakan pada pertemuan yang membahas kunci dikotom ini belum menerapkan pendekatan saintifik sesuai yang diminta oleh kurikulum 2013. Sedangkan untuk kesesuaian dengan karakteristik peserta didik, hasil analisis menunjukkan sesuai sebagian.

Komponen pemilihan media belajar terdiri dari kesesuaian dengan tujuan pembelajaran, kesesuaian dengan materi pembelajaran dan pendekatan saintifik, dan kesesuaian dengan karakteristik peserta didik. Untuk aspek kesesuaian dengan tujuan pembelajaran, hasil analisis menunjukkan sesuai sebagian. Hal ini dapat dilihat pada RPP, media yang digunakan kertas karton, tumbuhan dan hewan. Hal ini dirasa masih kurang sesuai dengan tujuan pembelajaran. Untuk aspek kesesuaian dengan materi pembelajaran dan pendekatan saintifik, hasil analisis menunjukkan sesuai sebagian. Hal ini dapat dilihat pada media yang digunakan dirasa kurang mendukung untuk pendekatan saintifik. Untuk aspek kesesuaian dengan karakteristik peserta 
didik, hasil analisis menunjukkan sesuai sebagian. Hal ini dapat dilihat dari penggunaan kertas karton yang cenderung kurang menarik bagi siswa SMP kelas VII.

Komponen model pembelajaran terdiri dari kesesuaian dengan tujuan pembelajaran dan kesesuaian dengan pendekatan saintifik. Untuk aspek kesesuaian dengan tujuan pembelajaran, hasil analisis menunjukkan sesuai sebagian. Hal ini dapat dilihat dari RPP yang menggunakan model discovery learning. Menurut pengamat untuk sub topic kunci dikotom kurang sesuai menggunakan discovery learning. Untuk aspek kesesuaian dengan pendekatan saintifik, hasil analisis menunjukkan sesuai sebagian. Hal ini dapat dilihat dari penggunaan model discovery learning yang dirasa kurang sesuai untuk kunci dikotom.

Komponen skenario pembelajaran terdiri dari menampilkan kegiatan pendahuluan, inti, dan penutup dengan jelas; kesesuaian kegiatan dengan pendekatan saintifik, kesesuaian penyajian dengan sistematika materi, dan kesesuaian alokasi waktu dengan cakupan materi. Untuk aspek menampilkan kegiatan pendahuluan, inti, dan penutup dengan jelas, hasil analisis menunjukkan sesuai sebagian. Hal ini dapat dilihat pada kegiatan ini tidak memasukkan klasifikasi makhluk hidup secara dikotomi. Pada RPP hanya sebatas kunci dikotomdan belum menyentuh klasifikasi makhluk hidup secara dikotomi. Untuk aspek kesesuaian kegiatan dengan pendekatan saintifik, hasil analisis menunjukkan sesuai sebagian. Hal ini dapat dilihat pada RPP tiap-tiap kegiatan belum mampu mengarahkan siswa untuk mengunakan pendekatan saintifik untuk mempelajari kunci dikotom. Untuk aspek kesesuaian penyajian dengan sistematika materi, hasil analisis menunjukkan sesuai sebagian. Hal ini dapat dilihat pada RPP tidak ada scenario untuk klasifikasi makhluk hidup secara dikotomi. Untuk aspek kesesuaian alokasi waktu dengan cakupan materi, hasil analisis menunjukkan tidak sesuai. Hal ini dikarenakan pada RPP tercantum alokasi waktu 3 JP, tetapi pada kegiatan inti tidak dijabarkan secara lebih rincilagi untuk alokasi waktu tiap kegiatan.

Komponen penilaian terdiri dari aspek kesesuaian dengan teknik dan bentuk penilaian autentik, kesesuaian dengan indikator, kesesuian kunci jawaban dengan soal, dan kesesuaian pedoman penskoran dengan soal. Keempat aspek setelah dianalisis menunjukkan sesuai seluruhnya. Hal ini dapat dilihat dari RPP yang telah mencantumkan penilaian untuk sikap, pengetahuan, maupun keterampilan.

\section{SIMPULAN}

Berdasarkan hasil analisis yang telah dilakukan pada RPP yang ditelaah, diperoleh kesimpulan bahwa penerapan kurikulum 2013 sudah berjalan dengan baik dalam aspek perencanaan pembelajaran yang tertuang dalam RPP. Semua komponen telah tercantum dalam RPP. Guru juga antusias dan berusaha menggunakan pendekatan saintifik dalam pembelajaran. Namun, terdapat beberapa hambatan yang harus diperbaiki terutama pada bagian pemilihan materi ajar. Ada beberapa komponen dari RPP yang harus diperbaiki. Pada pemilihan materi ajar guru hendaknya dapat mengorganisir materi secara runtut sehingga tidak terjadi kebingungan pada siswa saat pembelajaran. Kemampuan-kemampuan prasyarat yang harus dikuasai siswa juga harus dipertimbangkan dalam penyusunan RPP sehingga proses pembelajaran dapat berjalan sebagaimana mestinya.

\section{REFERENSI}

Agustiyana, D \& Widodo, S. (2014). Evaluasi Implementasi Kurikulum 2013 Kelas IV SD Negeri Banaran 1 Kertosono. Jurnal Maha Peserta Didik Teknologi Pendidikan Universitas Surabaya, 2(2): 3-9. 
Depdiknas. (2007). Standar Isi Untuk Satuan Pendidikan Dasar dan Menengah. Jakarta: Dirjen Dikti Depdiknas

Fogarty, Robin.(1991).The Mindful School: How To Integrate The Curricula. Palatine, Illinois: IRI/Skylight Publising. Inc.

Gerde, H.K. (2013). Using the Saintifik Method to Guide Learning: an Integrated Approach to Early Childhood Curriclum. Early Childhood Education Journal, 41(5): 315-323.

Hapsari, D.Y. (2015). Kemampuan Rata-rata Guru dalam Mengembangkan, Mengimplementasikan dan Mengevaluasi Kurikulum 2013. Indonesia Journal of Curriculum and Educational Technology Studies, 3(1): 22-28.

Krissandi, A.D.S \& Rusmawan. (2013). Kendala Guru Sekolah Dasar dalam Implementasi Kurikulum. Jurnal Cakrawala Pendidikan, XXXIV(3): 457-467.

Turpin, T \& Cage, B. (2004). The Effect of Integrated, Actifity-Based Science Curriculum on Student Achievement, Science Process Skills and Science Attitudes. Electronic Journal of Literacy through Science. Volume 3

Wikanengsih, dkk. (2015). Analisis Rencana Pelaksanaan Pembelajaran (RPP) Mata Pelajaran Bahasa Indonesia (Studi Terhadap RPP yang disusun Guru Bahasa Indonesia Tingkat SMP di Kota Cimahi). P2M STKIP Siliwangi. 2 (1), 106-1

Winny Liliawati, dkk. (2014). Analisis kemampuan inkuiri siswa smp, sma dan smk dalam penerapan levels of inquiry pada pembelajaran fisika. Jurnal Berkala Fisika Indonesia. 6 (2), 34-39. 